\title{
LWOWSKA KOPIA ZAGINIONEGO OBRAZU PĘDZLA IACOMO NEGRETTIEGO ZWANEGO PALMA IL VECCHIO
}

Od przeszło stu lat w prywatnych zbiorach w Krakowie znajduje się obraz Świętej Rodziny malowany temperą (?) na pergaminie. Spod wyblakłej malatury przebijają ciemne litery, albowiem podobrazie było pierwotnie dokumentem spisanym antykwa. Pergaminowy arkusz o wymiarach $45 \times 50 \mathrm{~cm} \mathrm{z}$ nieaktualnym tekstem wtómie wykorzystano malując na odwrociu obraz przestawiając przy tym format o 90 stopni. Dokument jest ozdobnym odpisem przywileju odpustowego nadanego przez papieża Piusa $\mathrm{VI}^{\prime}$ dla lwowskiego klasztoru Bernardynek w r. 1777. Na tym samym arkuszu, u dołu widnieje potwierdzenie autentyczności wystawione w pałacu obroszyńskim ${ }^{2}$ przez ówczesnego arcybiskupa lwowskiego Wacława Hieronima Sierakowskiego. Zatem zarówno odpis jak i potwierdzenie wystawiono łącznie w lwowskiej kurii arcybiskupiej ${ }^{4}$.

Odpust papieski został udzielony wszystkim, którzy nabożnie odwiedzą kościół klasztorny Panien Trzeciego Zakonu św. Franciszka pw. Niepokalanego Po-

${ }^{1}$ Pius VI, Giovanni Angelo Braschi (1717-1799). Papież od 1775 r. Bez powodzenia przeciwdziałał reformom cesarza Józefa II, przeciwnik rewolucji francuskiej, sprzymierzył się $z$ koalicją antynapoleońską. Internowany przez Francuzów zmarł w Valence nad Rodanem.

${ }^{2}$ Obroszyn, wieś w powiecie gródeckim, $14 \mathrm{~km}$ na zachód od Lwowa. Letni pałac arcybiskupów lwowskich wzniesiony tu został w r. 1760 z fundacji abp. Jana Skarbka. (Por. L. D z [i e dus z y ck i], Obroszyn, [w:] Stownik geograficzny Królestwa Polskiego, VII, Warszawa 1886 , s. $349-350$ )

${ }^{3}$ Wacław Hieronim Sierakowski h. Ogończyk (1700-1780), biskup inflancki (od r. 1738), kamieniecki (od r. 1739), przemyski (od r. 1742). Od r. 1759 arcybiskup metropolita lwowski. Kształcił się w Krakowie w szkole Nowodworskiego i w Uniwersytecie Krakowskim. Studia kontynuował w Rzymie, gdzie uzyskał stopień doktora obojga praw. W r. 1732 został kustoszem koronnym i powierzono mu nadzór nad renowacją zamku królewskiego na Wawelu. Popierając Stanisława Leszczyńskiego ukrywał przez trzy lata regalia, aby nie dopuścić do koronacji Augusta III. Później unikał zaangażowania politycznego, ale ganił wojewodę ruskiego Aleksandra Augusta Czartoryskiego za sprowadzenie wojsk rosyjskich i odegrał znaczna role w organizowaniu Konfederacji Barskiej. Zaliczany do najgorliwszych obrońców religii i Kościoła katolickiego. Przy lojalnej postawie wobec Austrii stanowczo sprzeciwiał się józefińskim reformom wprowadzanym po I rozbiorze. Przebudował pałace arcybiskupie we Lwowie, Dunajowie i Obroszynie. Zbierał książki, porcelanę, srebra i obrazy, także włoskie. Większość zapisał bratu Romanowi, sędziemu grodzkiemu krakowskiemu. Zmarł w obroszyńskim pałacu 29 X 1780 r. (Por. E. Burda, Waclaw Hieronim Sierakowski, [w:] Polski Słownik Biograficzny, XXXVII, Wrocław-Warszawa-Kraków 1996, s. 306-313).

${ }^{4}$ Por. ANEKS. 
częcia Najświętszej Panny Mari w święto Matki Boskiej Bolesnej. Według żywej ówcześnie tradycji tercjarki św. Franciszka, zwane później bemardynkami (a we Lwowie popularnie klaryskami), zostały sprowadzone z Krakowa do Lwowa za sprawą bł. Jana z Dukli, który obdarował je przy tym cudownym wizerunkiem Matki Boskiej Bolesnej. Stało się to zapewne w roku 1460 lub $1482^{5}$.

Reforma bernardynów polskich podjęta na początku wieku XVII objęła luźne wspólnoty Trzeciego Zakonu nową, surowszą regułą klasztorów klauzurowych. Wtedy to nowy kościół dla lwowskich bernardynek wzniósł Paweł Rzymianin w pobliżu Bramy Halickiej. W połowie następnego stulecia kościół i klasztor rozbudowano. W roku 1772 zgromadzenie liczyło 34 siostry $^{6}$.

Wystawienie rzeczonego przywileju odpustowego w roku 1777 przypada na dramatyczny w dziejach galicyjskich klasztorów okres tzw. reform józefińskich. Istotnym celem pozyskania odpustów wynikających z nawiedzenia cudownego obrazu było zwiększenie roli konwentu bernardynek w życiu religijnym Lwowa i przeciwstawienie się planowanej kasacie. Zarówno papież Pius VI jak i arcybiskup Sierakowski stanowczo, lecz bezskutecznie sprzeciwiali się oświeceniowym tendencjom rozdziału Kościoła od państwa, a zwłaszcza sekularyzacji majątków klasztornych. Pięć lat później, w roku 1782, za rządów uległego cesarzowi arcybiskupa Ferdynanda Kickiego lwowski klasztor bernardynek rozwiąano, kościól zamknięto, a obraz Matki Boskiej Bolesnej przekazano do kościoła OO. Bernardynów? ${ }^{7}$.

Można przypuszczać, iż ów ozdobny odpis papieskiego przywileju odpustowego wykonano w pięcioleciu 1777-1782. Później był już nieaktualny. Bezużyteczny arkusz pergaminu wykorzystano jako zaimprowizowane, niezagruntowane podobrazie . $^{8}$

Obraz św. Rodziny ${ }^{9}$ przyciaga uwagę bynajmniej nie ze względu na swą klasę artystyczną. Jest dzielem przeciętnym, a przy tym uszkodzonym. Poprzez spłowiałe pigmenty przebijają fragmenty tekstu [il. 1]. Charakterystyczna kolorystyka i typy fizjonomiczne postaci skłaniają do postawienia tezy, ze jest to kopia obrazu weneckiego z początku wieku XVI, bliskiego dziełom Iacomo Negrettiego (Nigrettiego), zwanego Palma il Vecchio (1479/1480-1528).

Kompozycja opiera się na dwu przenikających się liniach diagonalnych. Jedną tworzy sylweta Marii - jej twarz, welon i jej lewa ręka. Drugą diagonalę tworzy sylweta Dzieciątka, oraz prawa ręka i twarz św. Józefa.

Śpiąca Maria ujęta w półpostaci zajmuje przeszło połowę obrazu. Na kolanach trzyma zawinięte w pieluszkę Dzieciątko przytulone do odsłoniętej piersi. Twarz Marii jest idealizowana, o wysokich, wzniesionych łukach brwiowych i drobnych rysach. Czytelny jest tylko rysunek, gdyż światłocieniowy modelunek

${ }^{5}$ T. M a ńk owski, Dawny Lwów, jego kultura i architektura, Londyn 1974, s. 130132; H. E. Wy czawski (red.), Klasztory bernardyriskie w Polsce $w$ jej historycznych granicach, Kalwaria Zebrzydowska 1989, s. 526-528; B. K a c zorow s k i, Zabytki starego Lwowa, Warszawa 1990, s. 64-66.

${ }^{6}$ W y c zawsk i 1989, s. 527 ; K a c z orows k i 1990, s. 65.

${ }^{7}$ Tamże oraz P. P. G a c h, Kasaty zakonów na ziemiach dawnej Rzeczpospolitej i Slaska 1773-1914, Lublin 1984, passim.

${ }^{8}$ Konserwacje przeprowadziła Irena Bobrowska ok. 1948-1950.

${ }^{9}$ Pod względem ikonograficznym tytuł obrazu winien brzmieć „,Odpoczynek w drodze do Egiptu". 
został już starty (il. 2). Włosy o złotawym odcieniu, osłonięte są białym welonem. Suknia mocno spłowiała, była niegdyś w kolorze zbliżonym do różu pompejańskiego. Błękitny płaszcz rozciąga się dołem na całej szerokości tła.

Postać św. Józefa ustawiona jest na drugim planie. Widoczna jest tylko jego brodata twarz, podparta prawą ręką i zarys ramion otulonych brązową opończą.

Tło nie jest wyraźne, sylwety postaci wypełniaja niemal cały format. Można się tylko domyślać, że Maria opiera się o trzon kolumny (?), a powyżej ramienia św. Józefa rozjaśniony błękit jest fragmentem nieba odwzorowanego zgodnie z prawidłami późnorenesansowego umownego tła krajobrazowego.

Kolorystyka obrazu: różowo-czerwona suknia Marii, intensywny błękit jej płaszcza, biel welonu, ciepły odcień twarzy piersi i dłoni, miedziano-złote włosy przypominają wenecką konwencję kolorystyczną powielaną w dziełach Bellinich, Giorgione, a zwłaszcza Palmy il Vecchio. Równie charakterystyczna jest ogorzała twarz św. Józefa, ciepły brąz jego opończy, spod którego wystaje rękaw niebieskiej koszuli. Najważniejszą bowiem cechą nowożytnego malarstwa weneckiego jest specyfika kolorystyczna, dzięki której ciała i draperie miały mieć, jak mawiano, barwy muszli, kwiatów i nieba.

W opisywanym obrazie występuje sentymentalny typ postaci, o niewatpliwie rafaelowskim rodowodzie, ujętych w łatwych pozach, zawsze zwróconych do widza, lecz ich układ jest swobodny, jakby niedbały.

Charakterystyczne są typy fizjonomiczne postaci. One to właśnie stanowia przekonujące przesłanki pozwalające łączyć pierwowzór omawianego obrazu z kręgiem Iacomo Negrettiego. Widoczne na obrazie rysy twarzy Marii i Józefa spotyka się niemal na wszystkich jego obrazach. Podobnie typowa jest główka Dzieciątka. Rysy jego twarzy są zatarte, ale czytelne są wydęte policzki i charakterystyczna, wydłużona potylica podkreślona głębokim światłocieniem (il. 3).

Dobrymi przykładami porównawczymi sa obrazy Negrettiego przedstawiające św. Rodzinę lub Sancta Conversatione, gdyż były to tematy ulubione przez artystę: m.in. w Zbiorach Czartoryskich Muzeum Narodowego w Krakowie ${ }^{10}$, w Muzeum Narodowym w Poznaniu ${ }^{11}$, w praskiej Narodni Galerie (il. 4) ${ }^{12}$ a także w wiedeńskim Kunsthistorischesmuseum (il. 5) ${ }^{13}$. Bardzo zbliżony idealizowany typ kobiecej twarzy o lagodnie wzniesionych łukach brwiowych, prostym „,klasycznym" nosie i drobnych ustach i podbródku powtarza się także na „Portrecie młodej kobiety z naga piersią" w berlińskim Dahlem Museum [i1. 6] ${ }^{14}$ oraz na obrazie przedstawiającym „Lukrecję" w rzymskiej Galerii Borghese [il. 7] $]^{15}$.

Madonnę karmiącą namalował Negretti na obrazie znajdującym się jeszcze w r. 1772 w cesarskiej kolekcji w Wiedniu, dziś zaginionym, ale znanym z miedziorytu wykonanego około r. 1660 (il. 8).

${ }^{10}$ J. M y c i e ls k i, Galeria obrazów przy Muzeum ksiqżat Czartoryskich w Krakowie, Kraków 1893, s. 17; J. B i a ł o s t o c k i, M. W a l i c k i, Malarstwo europejskie w zbiorach polskich, Warszawa 1955, s. 475; Malarstwo weneckie XV-XVIII w. Katalog wystawy, Warszawa 1968, s. 128; P. R y l a d s, Palma Vecchio, Cambridge 1992, nr kat. A 20.

${ }^{11}$ B i ałostock i, W a l i cki 1955, s. 475; R y l and s 1992, nr kat. 30.

${ }^{12}$ R y l a nd s 1992, nr kat 10.

${ }^{13}$ Tamże, nr kat 50.

14 Tamże, nr kat. 80.

15 Tamże, nr kat. 88. 
„Nietypowa” dla Palmy jest tylko kompozycja układu postaci wypełniajacych cały format pergaminowego arkusza. Kopista ograniczony wielkością i proporcjami podobrazia był zapewne zmuszony do rekompozycji lub odrysował tylko fragment większej całości. Elementy krajobrazowe tła mogły być rozbudowane, ale diagonale sylwet postaci można uznać za pierwotne. Kaligrafia przerysu twarzy przypomina nieco maniere prerafaelicka, zatem omawiana kopia mogła powstać w połowie wieku XIX jeszcze we Lwowie, lub już w Krakowie.

$Z$ braku informacji źródłowych wszelkie rozważania na temat domniemanego szesnastowiecznego oryginału - nieznanego, a najpewniej i niezachowanego mają charakter wyłącznie poszlakowy. Wenecki obraz powstały w kregu Iacomo Negrettiego mógł znajdować się w sławnej prywatnej kolekcji arcybiskupa Sierakowskiego ${ }^{10}$. Niewykluczone, że zarówno ów obraz jak i nieaktualny już ozdobny odpis na pergaminie mogły zostać przekazane $w$ masie spadkowej znanym zapisem testamentowym dla brata arcybiskupa, Romana Sierakowskiego, do Krako$\mathrm{wa}^{17}$. Jeżeli tak istotnie było, to niniejszą kopię należałoby nazwać „krakowską", a nie „lwowską", jak w tytule artykułu. Sa to jednak tylko przypuszczenia, a stan zachowania nie pozwala na bardziej wnikliwą analizę.

Mimo zniszczeń spłowiała kopia dobrze oddaje charakter pierwowzoru, przywołuje poetyczny nastrój weneckich obrazów, „daje radość, budzi delektację, upaja blaskiem, kolorem, natchnieniem"18.

\section{Lviv Copy of Missing Painting by Iacomo Negretti Called Palma Il Vechio Summary}

For over a hundred years in a private collection in Cracow there has been a distemper painting on parchment with an image of the Holy Family. Dark letters show through the faded front as the back was originally a document written in the Roman type. When the document expired, the other side of the parchment was used for a painting and the format was moved by 90 degrees. The document is a decorated copy of a church fair privilege given by pope Pius VI to the Bernardine Nuns in Lviv in 1777. At the bottom there is an authentication issued in the Obroszyn castle by a Lviv archbishop Wacław Hieronim Sierakowski. Thus, both the copy and the authentication were issued jointly in Lviv Archbishop Curia in Lviv.

${ }^{16}$ Por. B u r d a 1996, s, 312.

${ }^{17}$ Tamże.

${ }^{18}$ J. B i a ł o s t o c k i, Odrębność sztuki weneckiej, [w:] Malarstwo weneckie..., dz. cyt., 1968 , s.13. 
A NEKS:

PIUS PAPIEŻ VI

\section{DO WIECZNEY RZECZY PAMIĘCI.}

Dla pomnożenia w Wiernych pobożności y dusz zbawienia, nad Niebieskimi Kościoła Skarbami będąc Przełożonemi Wszystkim y Każdym z osobna oboyga płci Wiernym Chrystusowym prawdziwie pokutującym wyspowiadanym y świętą Komunią zasilonym, którzyby Kościół pod tytułem Niepokalanego Poczęcia Błogosławioney MARII Panny Zakonnic trzeciey Reguły S. Franciszka miasta Lwowa w piątek po niedzieli nazwaney bialey (:to jest Święto Nays: MARII Bolesney:) od pierwszych nieszporów aż do zachodu słońca w którymkolwiek roku dnia rzeczonego nabożnie odwiedzili y tamże za Xiążąt Chrześciańskich zgoda za herezij wykorzenienie y za S. Matki Kościola podwyższenie nabożne do Boga modły wyleli zupełnego wszystkich grzechów Odpustu i przebaczenia miłościwie w Panu pozwalamy. Nad tymże Chrystusowym Wiernym za grzechi swoje przynajmnicy żałującym przerzeczony Kościół w każdy y którykolwiek całego roku piątek odwiedzajacym y w nim jako wyżey modlącym się dnia tego w którem to uczynią dni dwieście Kar zaciagnionych według zwyczayney formy Kościoła relaxujemy. Niniejszym pozwoleniem wiecznemi $\mathrm{p}$ [rz]eszłemi czasy mającym ważyć. Dan w Rzymie pod Pierścieniem Rybaka. Dnia xix miesiąca Lutego MDCCLXXVII [Papies]twa Naszego Roku drugiego.

(M.P.)

I. Kardynał z komesów.

WACŁAW HIERONIM HRABIA SIERAKOWSKI

Z Bożey y Stolicy Apostolskiey Laski Arcybiskup Metropolita Lwowski wysokiego Ordera S. Stefana Króla Apostolskiego wielkiego Krzyża Kawaler, Świętych Cesarskich Apostolsko = Królewskich Majestatów ninieyszy Zaufny Stanu Konsyliarz.

Wszystkim y każdemu z osobna do których[by] ........ lub należy oznaymujemy: że My, widziawszy y przeczytawszy wyżey wyrażone pismo całe zupełne y nienarusz[one Wł]adzą Pas[t]erstwa Naszego one przyiąć y zachować za słuszność osądziliśmy jakoż co do ...... wyraźney słowności we wszystkim przyieliśmy y aby Wiernym Chrystusowym obwieszczone byłe pozwolenie daliśmy w Pałacu Naszym Arcybiskupim Obrosz[eńskiem] Dnia xxv Czerwca Roku Pańskiego MDCCLXXVII

$$
\text { + Wacław Arcybiskup }
$$




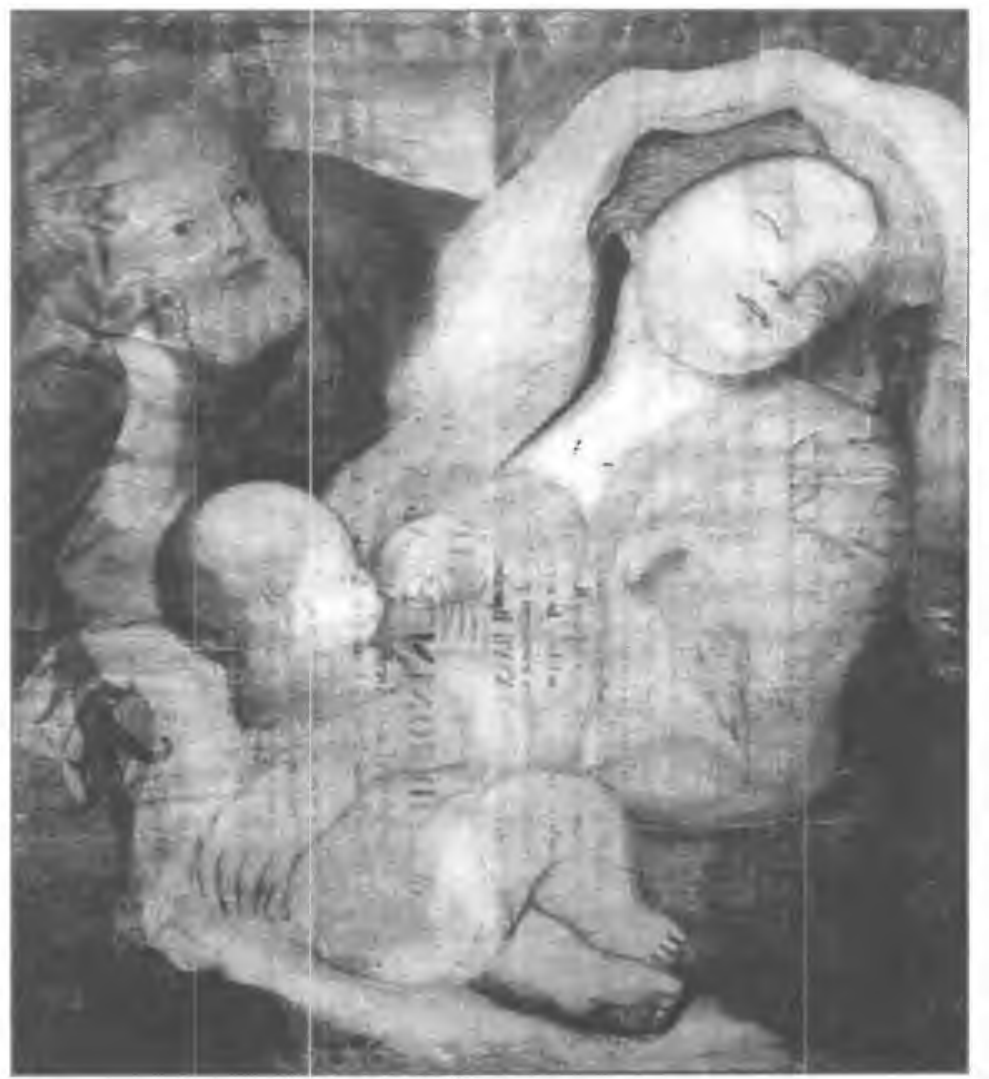

1. N. N., Święta Rodzina [Odpoczynek w drodze do Egiptu], tempera na pergaminie, polowa w. XIX (?) (fot. archiwalna ze zbiorów prywatnych). 


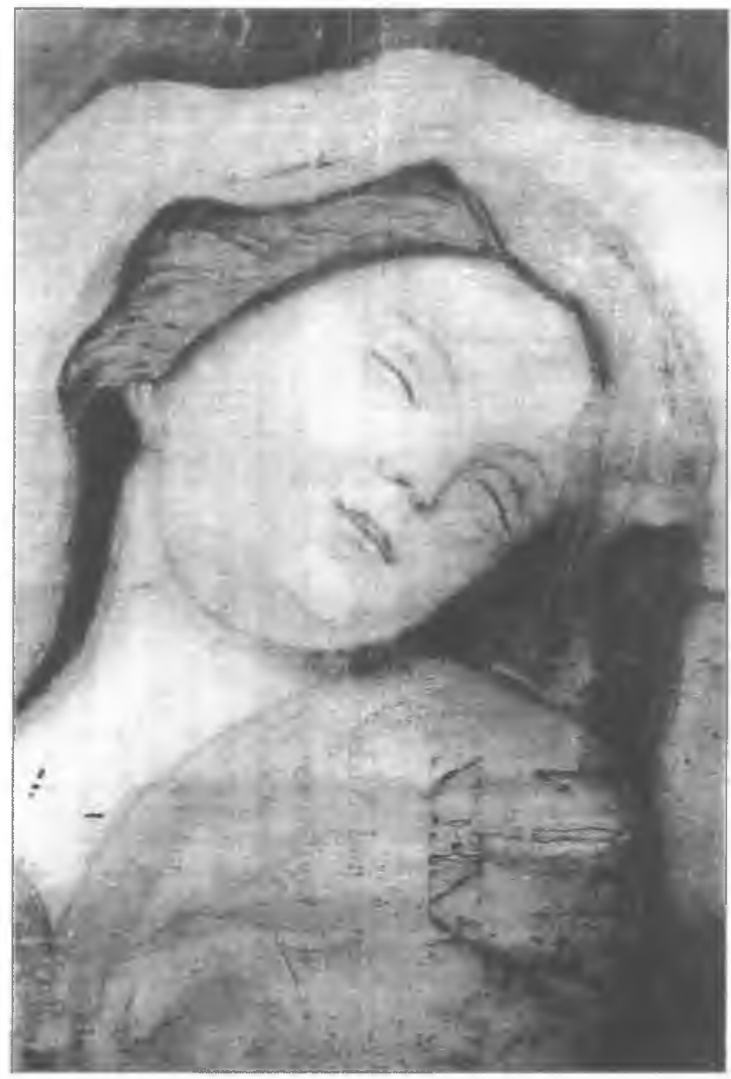

홍

2. Twarz Marii, [fragment il. 1]. 


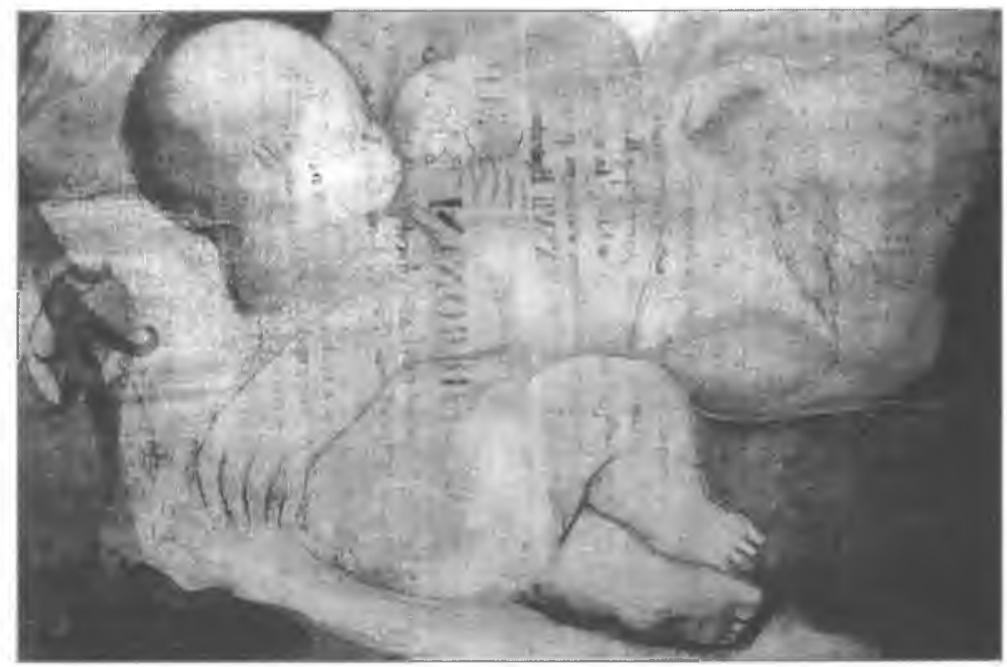

3. Dzieciątko Jezus, [fragment il. 1].

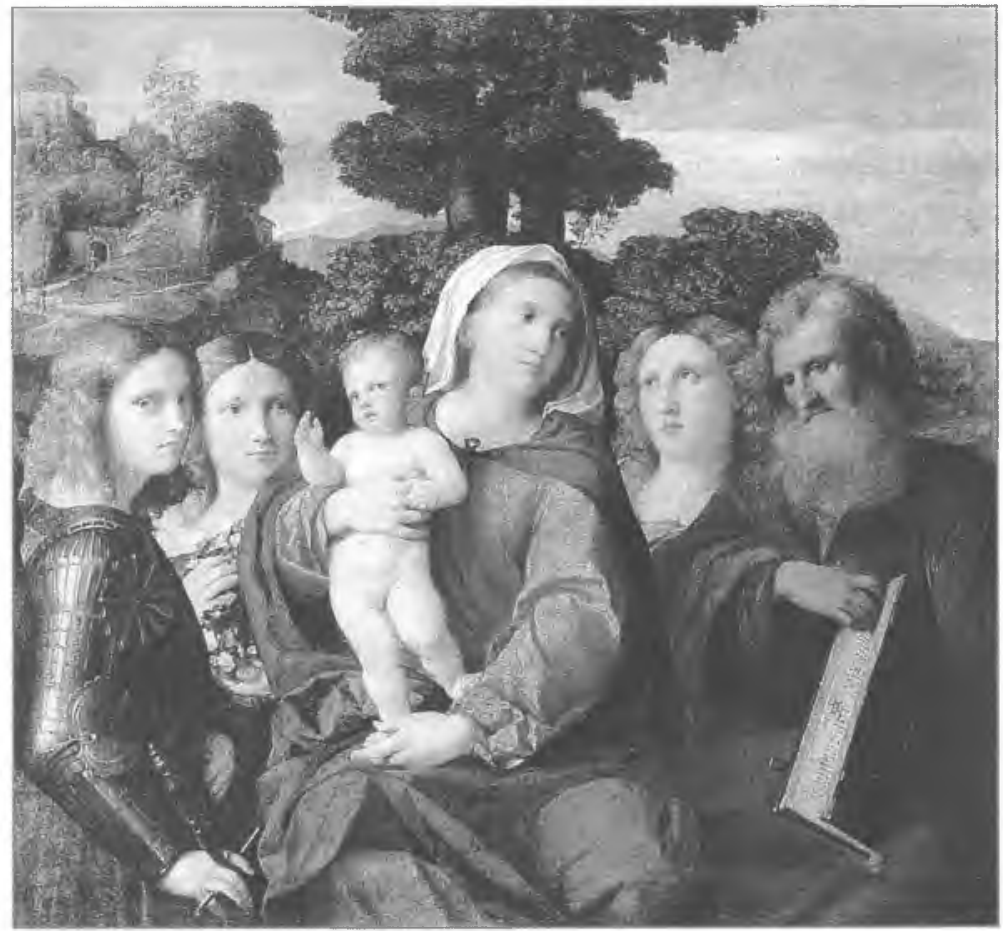

4. Palma Vecchio, Madonna z Dzieciątkiem, ze Św. Michatem, Św. Dorota, Św. Mariq Magdalena i Św. Józefem, olej na płótnie, ok. 1513, Praga, Narodni Galerie, (fot. wg Rylands 1992, nr kat. 10). 


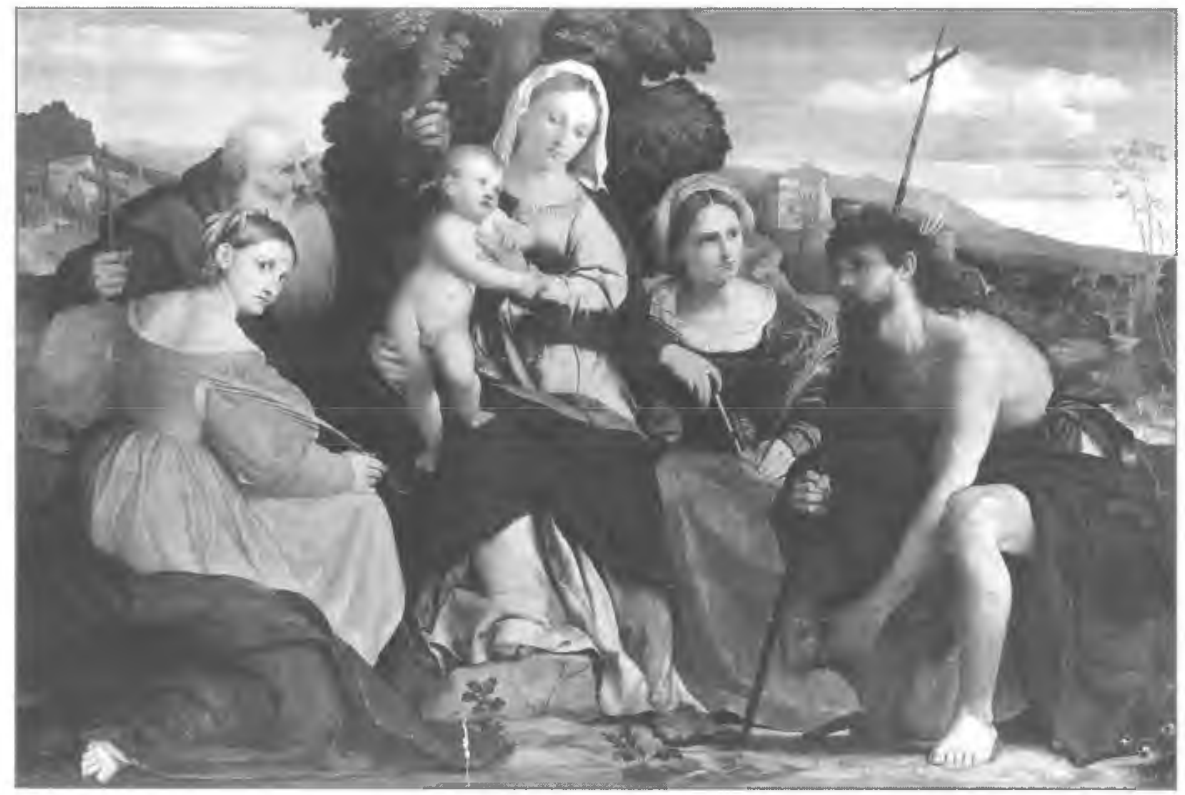

5. Palma Vecchio, Madonna z Dzieciątkiem, ze Św. Katarzyna, Św. Barbara, Św. Celestynem i $S w$. Janem Chrzcicielem, olej na desce, ok. 1520-1522, Wiedeń, Kunsthistorischesmuseum, (fot. dzięki uprzejmości Bundesdenkmalamt w Wiedniu).

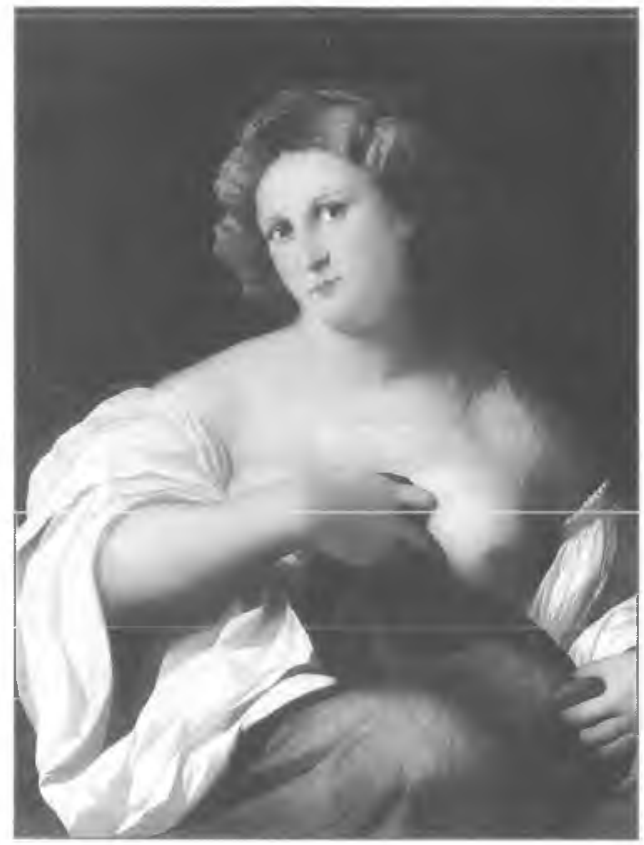

6. Palma Vecchio, Portret mtodej kobiety $z$ naga piersia, olej na desce, ok. 1524-1526, Berlin, Dahlem Museum, (fot. wg Rylands 1992, nr kat. 80). 
7. Palma Vecchio, Lukrecja, olej na desce, ok. 1525-1528, Rzym, Galeria Borghese, (fot. wg Rylands 1992, nr kat. 88).
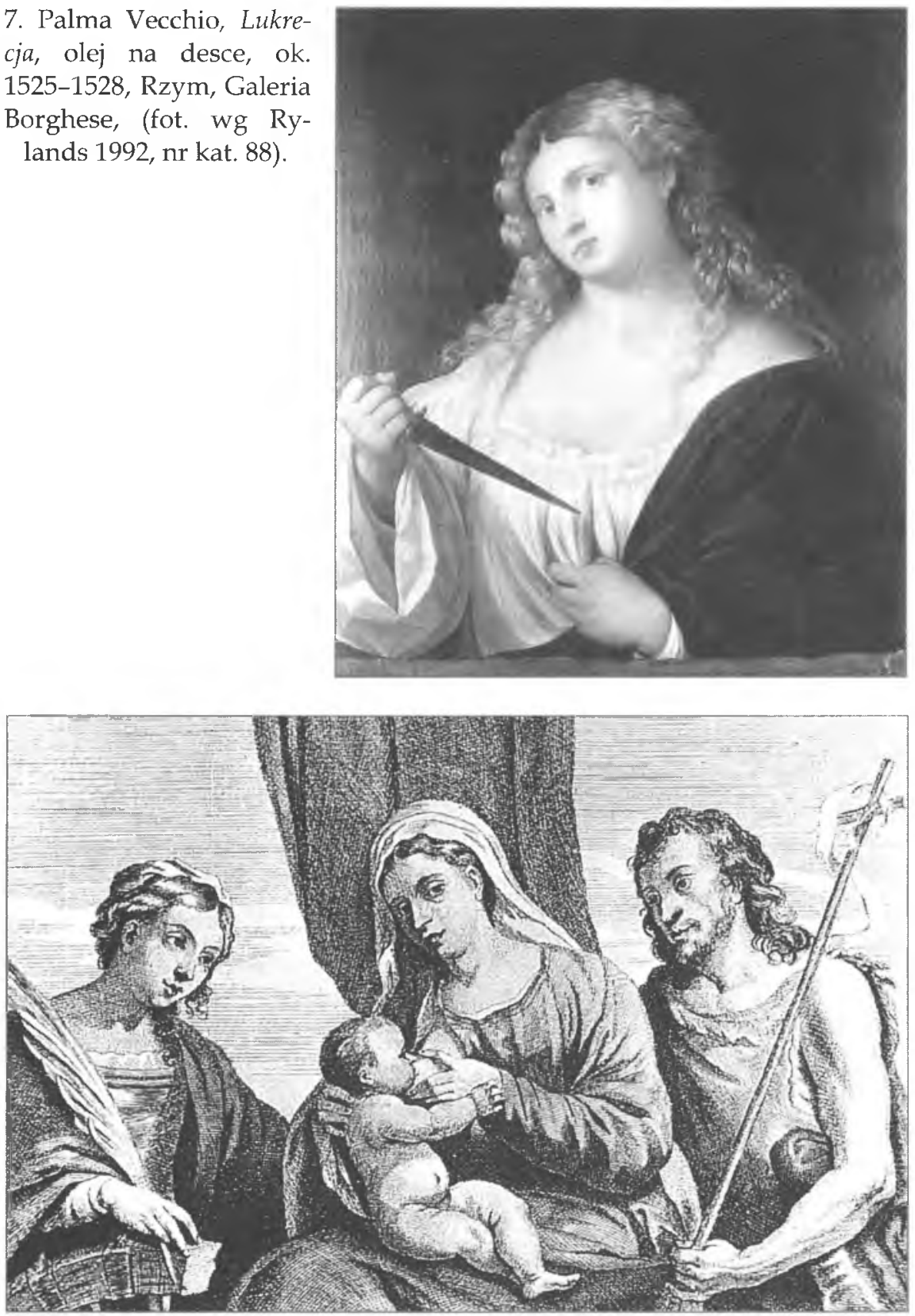

8. Madonna karmiaca ze Św. Janem Chrzcicielem i Św. Katarzyna, miedzioryt

I. Popelsa z r. 1660 wg zaginionego obrazu Palmy il Vecchio, (fot. wg Rylands 1992, nr kat. X81). 